\title{
OXT Gene
}

National Cancer Institute

\section{Source}

National Cancer Institute. OXT Gene. NCI Thesaurus. Code C39649.

This gene plays a regulatory role in smooth muscle contraction during processes such as parturition and lactation. 